\title{
Az antidiabetikumok hatása a kardiovaszkuláris biztonságosságra és a szívelégtelenségre - ahogy a kardiológus látja
}

\author{
Rábai Miklós dr., Habon Tamás dr.
}

\begin{abstract}
Osszefoglalás
A kardiovaszkuláris rendszerre ható, evidenciákon alapuló kezelés mellett a cukorbetegség makrovaszkuláris szövődményeinek kialakulását az elsö antidiabetikumok érdemben nem csökkentették. Ezzel szemben az elmúlt évek kardiovaszkuláris biztonságosság jegyében elvégzett klinikai tanulmányai az új támadáspontú készitményekkel (GLP-1-analógok és SGLT2-gátlók) kapcsolatban már sikerekröl is beszámoltak a legfontosabb kardiovaszkuláris események (MACE) és a szivelégtelenség miatti kórházi kezelések számának tekintetében. Ezen eredményeket az SGLT2-gátló készitményekkel (empagliflozin, canagliflozin és dapagliflozin) kapcsolatban elvégzett legújabb, valóélet-adatokon alapuló vizsgálatok (CVD-REAL és CVD-REAL Nordic) eredményei támogatják és kiegészitik. A pozitiv eredményeket felvonultató tanulmányokat a 2-es típusú cukorbetegek kardiológiai ellátása és az antidiabetikus gyógyszerválasztás során figyelembe kell venni.
\end{abstract}

Kulcsszavak: antidiabetikus kezelés, kardiovaszkuláris események, szivelégtelenség, klinikai vizsgálatok

\section{Effects of antidiabetics on cardiovascular safety and heart failure - from the point of view of a cardiologist}

Summary: Besides the evidence based cardiovascular therapy, evolution of the macrovascular complications in diabetes mellitus was not substantively decreased by the first antidiabetics. In contrast, recent clinical trials, performed in connection with cardiovascular safety and new therapeutical approaches (GLP-1 analogs and SGLT2 inhibitors), have already reported successful results regarding the number of major cardiovascular events (MACE) and heart failure hospitalizations. These outcomes have been supported and completed by the results of the newest studies (CVD-REAL and CVD-REAL Nordic) demonstrating real world data about the SGLT2 inhibitor therapies (empagliflozin, canagliflozin and dapagliflozin). The trials, presenting positive results, should be taken into account in cardiac care and during the initiation of antidiabetic therapy.

Key words: antidiabetic treatment, major cardiovascular events, heart failure, clinical trials

\section{Rövidítések}

CI: konfidenciaintervallum (confidence interval); CV: kardiovaszkuláris (cardiovascular); DPP-4: dipeptidil-peptidáz-4 (dipeptidyl peptidase-4); GLP-1: glukagonszerü peptid-1 (glucagon-like peptide-1); HR: esélyhányados (hazard ratio); MACE: nagy kardiovaszkuláris események (major cardiovascular events); NPH: neutrális protamin Hagedorn szerint készített inzulin; RAS: renin-angiotenzin rendszer (renin-angiotensin system); SGLT2: nátrium-glukóz kotranszporter-2 (sodium-glucose cotransporter-2) 
$\mathrm{K}$ orábban a cukorbetegek mortalitásáért a hyperglykaemia akutan bekövetkező ha(ketoacidosis vagy hyperosmolaris coma) voltak felelősek. Ma a betegség hosszú távú kimenetelét alapvetően a kardiovaszkuláris (CV) szövődmények (macro- és microangiopathia) kialakulása határozza meg. ${ }^{1}$

A hyperglykaemia hatására hosszú távon irreverzibilis változások következnek be a szervezetben, amelyek kezdetben a szövetek szintjén funkcionális, később strukturális változásokhoz is vezetnek. Az anyagcsereutak megváltozása, a glikációs végtermékek és szabad gyökök megjelenése az örökítő anyag és a fehérjék szerkezetében, így a molekulák funkciójában okoz változást. Ennek eredményeként endotheldiszfunkció (vazokonstrikciós hajlam, a permeabilitás fokozódása, a thrombosiskészség növekedése, megváltozott reológiai viszonyok), valamint az extracelluláris sejtek és a mátrix proliferációja alakul ki, ez pedig elvezet a cukorbetegség mikrovaszkuláris (nephropathia, neuropathia, retinopathia) és makrovaszkuláris szövődményeihez (koszorúér-betegség, szívelégtelenség, stroke, perifériás érbetegség).

Ismert, hogy cukorbetegek esetében a CV rizikó az egészséges populációhoz képest legalább kétszer nagyobb. ${ }^{2}$ A myocardium vérellátását rontó, koszorúereken kialakuló atheroscleroticus szükületek anginás panaszokhoz, myocardialis infarctushoz, ischaemiás cardiopathiához, azaz csökkent ejekciós frakciójú szívelégtelenség kialakulásához és hirtelen halálhoz is vezethetnek.

Ezzel szemben mind az 1-es, mind a 2-es típusú cukorbetegség koszorúér-betegség kialakulása nélkül is a myocardium károsodását eredményezheti. Az állapot diabeteses cardiopathiaként is ismert, kialakulásában a cukorbetegség metabolikus folyamatai játsszák a főszerepet. ${ }^{3}$ A hyperglykaemia következtében létrejövő glikációs végtermékek, oxidatív szabad gyökök és aktiválódó inflammatórikus molekulák, valamint a fokozott zsírsavfelvétel és -akkumuláció károsítja a szívizomsejtek működését. Apoptosis és kötőszöveti átépülés, intramyocardialis fibrosis alakul ki. Emellett az aktiválódó RAS rendszer következtében a szívizomzat hipertrofizál. A folyamatok eredményeként a bal kamra izomzata átépül, remodelláció következik be. Ennek következtében pedig romlik a szívizomzat kontraktilitása, és csökken a rugalmassága, diasztolés funkciózavar alakul ki, ami megtartott ejekciós frakciójú szívelégtelenség kialakulásához vezethet.

A fentiek alapján nem meglepő, hogy cukorbetegség mellett a szívelégtelenség kialakulásának kockázata kétszer nagyobb, mint az egészséges populációban. ${ }^{4}$ A szívelégtelenség prevalenciája cukorbetegség mellett 10-23\%, ugyanakkor ez visszafelé is igaz; szívelégtelenség mellett nagy eséllyel alakul ki inzulinrezisztencia és cukorbetegség, a cukorbetegség prevalenciája szívelégtelenség mellett akár 40-45\% is lehet. Ezek alapján a szívelégtelenség a második leggyakrabban kialakuló CV szövődménynek számít a cukorbetegek körében.

\section{Célkitüzés}

A jelen értekezés célja az antidiabetikumokkal végzett klinikai tanulmányok eredményeinek főként makrovaszkuláris komplikációk szemszögéből való áttekintése, a CV kimenetelre és a szívelégtelenségre gyakorolt hatások részletezése, valamint az eredményeknek a mindennapi kardiológiai gyakorlatban való elhelyezése.

\section{Az antidiabetikus terápia}

Ismert, hogy az antidiabetikumok általi vércukorés $\mathrm{HbA}_{1 \mathrm{c}}$-szint-csökkenés a microangiopathiás szövődmények kialakulását jelentősen mérsékli (UKPDS, ADVANCE, VADT vizsgálatok), ${ }^{5}$ ugyanakkor a macroangiopathiás szövődmények tekintetében jelentős eredményt igazolni a közelmúltig nem sikerült. ${ }^{6}$ Az UKPDS vizsgálatban a myocardialis infarctus előfordulása $14 \%$-kal, míg a stroke gyakorisága $12 \%$-kal csökkent, ugyanakkor az ADVANCE és a VADT vizsgálat megfelelő vércukorkontroll esetén sem talált csökkenést a makrovaszkuláris komplikációk előfordulásában, míg az ACCORD vizsgálatot az intenzíven kezelt csoportban észlelt magasabb mortalitás miatt le is kellett állítani. A tanulmányok eltérő eredményeit több tényezővel is magyarázták; a későbbi vizsgálatokba idősebb betegpopuláció került bevonásra, emellett nagyobb arányú volt a hatékony statinterápia és vérnyomáskontroll alkalmazása, ugyanak- 
kor a gyógyszerek okozta mellékhatások (pl. hypoglykaemia) szerepe sem volt elhanyagolható.

A cukorbetegség terápiájában az alacsony szénhidráttartalmú diéta és a fizikai aktivitás mellett a gyógyszeres terápia folytatása is elengedhetetlen. A gyógyszerek ${ }^{7}$ közötti választásban az Amerikai Diabetes Társaság (ADA) és az Európai Diabetes Társaság (EASD) 2015-ös konszenzusajánlása ${ }^{8}$ nyújt segítséget. A 2017-es magyar diabetológiai szakmai irányelv is e vonalak mentén fogalmazódott meg. ${ }^{9}$ Ezen terápiás eszközök sikeres alkalmazásával érhető el a kezelés eredményességét lemérő $\mathrm{HbA}_{1 \mathrm{c}}$-céltartomány: 6,0-8,0\%. Ugyanakkor egyes betegeknél (pl. idősek) a szigorú vércukorkontroll és az ideálisan választandó terápia helyett személyre szabott kezelés alkalmazása szükséges, amellyel egy individuálisan meghatározott célérték elérésére kell törekedni.

A fentiek alapján az ideális antidiabetikus gyógyszer nemcsak a vércukorszintet normalizálja, hanem a betegség késői szövődményeit is megelőzi, illetve azok progresszióját lassítja; vagyis a készítmény alkalmazása a mortalitás csökkentését és az életminőség javulását eredményezi. Ezek mellett az ideális gyógyszert a betegek széles köre mellékhatások nélkül (pl. testsúlygyarapodás, hypoglykaemia), jó adherenciával tudja használni.

\section{A 2-es típusú cukorbetegség első antidiabetikumai}

Jelenleg a 2-es típusú cukorbetegségben az antidiabetikus terápia elsőként választandó gyógyszere a glukoneogenezist gátló és a szöveti inzulinrezisztenciát csökkentő metformin, amelyről az UKPDS tanulmányban $\mathrm{CV}$ rizikót csökkentő eredményekről számoltak be. Ezzel szemben a későbbiek folyamán elvégzett metaanalízisek eltérő eredményeket igazoltak a CV kimenetel terén, azonban rizikót növelő hatás nem igazolódott. Az inzulinelválasztást fokozó szulfanilureák a mellékhatásként jelentkező hypoglykaemia miatt akár a CV mortilitást is fokozhatják, szedésük - metforminnal összehasonlítva - magasabb CV rizikót jelent. A szintén inzulinszekréciót serkentő glinidekkel végzett retrospektív vizsgálatok a $\mathrm{CV}$ rizikó tekintetében semleges eredményt hoztak. A glukóz felszívódását gátló akarbózt illetően, a fenti kérdésben korábban inkább pozitívak voltak az ered- mények, ugyanakkor a közelmúltban publikált ACE vizsgálat (Acarbose Cardiovascular Evaluation) a diabetes incidenciájának csökkenése mellett nem igazolta a CV kockázat csökkenését csökkent glukóztoleranciájú betegekben. ${ }^{10} \mathrm{~A}$ jelenleg elfogadott, ugyanakkor sokat vitatott vélemény szerint, a tiazolidin-dionok közül a roziglitazon a CV halálozást fokozta. ${ }^{11}$ A pioglitazon használata CV szempontból semlegesnek bizonyult az elsődleges végpont alapján, a szívelégtelenség rizikójának fokozása miatt azonban alkalmazása óvatosságot igényel.

\section{Az inkretinrendszerre ható szerek}

A roziglitazon piacról történő kivonása óta az antidiabetikus gyógyszerek CV biztonságosságának kérdése központi tényezővé vált, amelyet az új készítmények tekintetében az FDA előírása nyomán nagy, multicentrikus, kettős vak, randomizált tanulmányok keretében vizsgálni szükséges. Az inkretinrendszerre ható szerek közül az elsőként vizsgált készítmények a glukózfüggő inzulinfelszabadulást serkentő glukagonszerü peptid-1 (GLP1) lebontását végző dipeptidil-peptidáz-4 enzim működését gátló (DPP-4-gátlók) orális készítmények voltak. A saxagliptin a SAVOR-TIMI 53, ${ }^{12}$ az alogliptin az EXAMINE, ${ }^{13}$ míg a sitagliptin a TECOS $^{14}$ vizsgálatokban non-inferiornak bizonyult a placebóhoz képest, vagyis a készítmények CV szempontból biztonságosnak tekinthetőek.

Fontos hangsúlyozni, hogy a tanulmányokat kifejezetten biztonságossági és nem hatékonysági szempontok igazolása céljából tervezték. Illetve azt is érdemes kiemelni, hogy az alogliptin a számszerű adatokat tekintve, míg a saxagliptin statisztikailag is szignifikáns mértékben fokozta a szívelégtelenség miatti hospitalizációk számát $(3,5 \%$, illetve 2,8\%; $\mathrm{HR}=1,27$; 95\%-os CI: $1,07-1,51$; $\mathrm{p}=0,007)$. Ugyanakkor a szívelégtelenség miatti mortalitás egyik készítmény esetében sem növekedett. A szívelégtelenség miatti kórházi kezelések számának fokozódása a korábban már szívelégtelenség miatt kezelt betegeken túl a szívelégtelenség tekintetében alacsony rizikóval rendelkezők körében is megfigyelhető volt. A hospitalizációk száma a terápia megkezdését követő egy éven belül nőtt meg jelentősen, ezt követően a szívelégtelen események előfordulása nem különbözött a 
placebóval kezelt populációban észleltektől. Ennek hátterében megbújó ok, esetleges mechanizmus egyelőre nem igazolódott.

A parenterálisan adandó GLP-1-analógok és receptoragonisták közül a kifejezetten rövid, párórás felezési idejű, napi egyszeri adagolású lixisenatid az ELIXA tanulmányban ${ }^{15}$ a CV rizikó szempontjából semlegesnek bizonyult. A heti egyszeri adagolású, legalább 4 napos felezési idővel rendelkező exenatid kardiovaszkuláris biztonságosságát a nagy elemszámú, hosszú utánkövetési idejű EXSCEL vizsgálatban ${ }^{16}$ igazolták. Az elsődleges összetett végpontba tartozó esemény az exenatidcsoportban a betegek 11,4\%-ában következett be, míg a placebocsoportban $12,2 \%$-ban (HR: 0,91; 95\%-os CI, 0,83-1,00). Az exenatid non-inferiornak bizonyult a placeboághoz képest a biztonságosság tekintetében $(p=0,001)$, de nem érte el a szuperioritást a hatékonyságra vonatkozóan $(\mathrm{p}=0,06)$.

A szintén heti egyszeri adagolású, kifejezetten hosszú felezési idejű semaglutid, a noninferioritás bizonyítására megtervezett SUSTAIN-6 vizsgálatban kis elemszámú, cukorbeteg betegpopuláción, kétéves időtartam után szuperiornak $(\mathrm{HR}=0,74$; 95\%-os CI: $0,58-0,95 ; \mathrm{p}=0,02)$ bizonyult a placebóval szemben az összetett elsődleges kardiovaszkuláris végpont (MACE: kardiovaszkuláris halálozás, nem végzetes myocardialis infarctus és nem végzetes stroke) tekintetében. ${ }^{17}$ A MACE kedvező irányú változása elsődlegesen a nem fatális stroke-ok számában bekövetkező szignifikáns csökkenésnek volt tulajdonítható, ehhez kismértékben hozzájárult a nem fatális myocardialis infarctusok számának csökkenése is, ugyanakkor a kardiovaszkuláris halálozás a két csoportban lényegében megegyezett. Biztonságossági szempontból a retinopathia előfordulásának emelkedése vetett fel kérdéseket.

Egy másik GLP-1-receptoron ható készítmény, a liraglutid a LEADER tanulmányban egy nagy betegpopulációnál, hosszú távon alkalmazva szignifikáns csökkenést eredményezett a MACE-ben (HR $=0,87 ; 95 \%$-os CI: 0,78-0,97; $p=0,01)$. Az elsődleges végpontban bekövetkező csökkenéshez mindhárom összetevő hozzájárult, de ezek közül is erősen szignifikáns csökkenést lehetett észlelni a kardiovaszkuláris halálozás tekintetében. A liraglutid a szívelégtelen esetek előfordulását számszerűen ugyan csökkentette, de szignifikáns különbséget a két csoport között nem észleltek $(\mathrm{HR}=0,87 ; 95 \%$-os CI: $0,73-1,05 ; \mathrm{p}=0,14) .{ }^{18}$

A fenti tanulmányok eredményéből következik, hogy a DPP-4-gátlók és a GLP-1-receptoron ható készítmények közt a CV kimenetel tekintetében észlelt különbségek hátterében a vizsgálatok eltérő felépítésén túl leginkább a különböző hatásmechanizmus állhat. A DPP-4-gátlók növelik az endogén GLP-1 szintet, de a GLP-1-receptoron ható szerek a fiziológiásnál lényegesen nagyobb GLP-1 hatást válthatnak ki. Ezen túlmenően a DPP-4gátlóknak eltérő hatásuk is lehet (pl. a glukózdependens inzulinotróp polipeptidszint növelése), más endogén útvonalakat is gátolhatnak, ez pedig megmagyarázhatja a két csoport hatása közti különbséget a CV rizikó csökkentés tekintetében. A tanulmányok azt is megmutatták, hogy a GLP-1-analógok (semaglutid és liraglutid) jobban teljesítettek, mint a GLP-1-receptor-agonisták (lixisenatid, exenatid). A lixisenatid tanulmányába bevont betegek kevesebb mint 6 hónappal voltak csak túl egy lezajlott, akut coronariaeseményen, vagyis a betegpopuláció némileg eltért a többi vizsgálat beteganyagától. A különböző eredmények a készítmények eltérő farmakokinetikai (pl. felezési idő) és farmakodinámiás jellemzőivel is magyarázhatóak. A semaglutid- és a liraglutid-tanulmányok eredményeiben észlelt különbség pedig a vizsgálatok betegszámának és az utánkövetés hosszúságának különbözőségéből eredhet. A CV mortalitás csökkentéséhez hosszabb terápiás időre, jelen esetben legalább kétéves gyógyszeres kezelésre van szükség. A semaglutiddal végzett vizsgálat egy piacra lépés előtti, engedélyeztetési vizsgálat volt, amelyet feltehetően egy új, nagyobb elemszámú, hosszabb utánkövetési idejű vizsgálat fog követni.

\section{Az inzulinterápia}

A 2-es típusú diabetes mellitus kezelésében az inzulinterápia leginkább a per os gyógyszeres terápia sikertelensége, a pancreas béta-sejtjeinek kimerülése esetén kerül tartósan bevezetésre. A kezelés bevezetésekor a lehetséges terápiás rezsimek (bázisinzulinnal kiegészített orális antidiabetikum-terápia, prandialis inzulinkezelés, intenzív konzervatív inzulinterápia, konvencionális inzulin- 
kezelés) közül az adott beteg számára legelőnyösebbet kell választani. A terápia során az inzulinanalógokat a kedvezőbb hatásprofil miatt érdemes előnyben részesíteni a humán inzulinokkal szemben, ugyanis a hosszú hatású, napi egyszer (glargin, degludek), illetve egyszer vagy kétszer adott inzulinanalóg (detemir) és a többször adott gyors hatású inzulinanalóg kombinációja jobb vércukorbeállítást eredményez, valamint csökkenti a hypoglykaemia kockázatát, mint a humán bázis-bólus kezelési rendszer.

A HEART2D tanulmányba ${ }^{19}$ bevont, korábban myocardialis infarctuson átesett cukorbetegek körében a prandialis (étkezések előtt napi 3 alkalommal adott lispro inzulin) és a bázisinzulin-terápia (napi 2 alkalommal adott NPH vagy napi 1 alkalommal adott glargin inzulin) alkalmazása között a CV események előfordulása terén érdemi különbséget nem sikerült kimutatni.

A hosszú hatású inzulinanalógok közül a glargin inzulinnal kapcsolatban elvégzett ORIGIN tanulmány ${ }^{20}$ a készítményt $\mathrm{CV}$ és tumorrizikó szempontjából biztonságosnak találta. Prediabeteses betegeknél alkalmazva az újonnan kialakult cukorbetegség rizikója szignifikánsan csökkent, és ahogy az várható volt, a hypoglykaemia gyakrabban fordult elö, valamint a betegek testsúlya kismértékben nőtt.

A DEVOTE vizsgálatban ${ }^{21}$ a degludek inzulint a CV biztonságosság tekintetében non-inferiornak, míg a hypoglykaemia tekintetében szuperiornak találták a glargin inzulinnal szemben $(4,9 \%$, illetve 6,6\%; RR: 0,6; 95\%-os CI: 0,48-0,76; $\mathrm{p}=0,001)$.

\section{A nátrium-glukóz kotranszporter-2 (SGLT2) gátlók}

Az előző készítményektől eltérő módon, a nátrium-glukóz kotranszporter-2 gátlók inzulintól függetlenül fejtik ki hatásukat, gátolják a vese tubulusaiban a glukóz visszaszívódását, így glucosuriát okoznak. A hatékony vércukorszint-csökkentésen túl (hypoglykaemia nem fordul elő) alkalmazásuk mellett csökken a testsúly (a glucosuria kalóriavesztést okoz és a visceralis zsír jelentősebb mértékű csökkenése mellett a subcutan zsírszövet is csökken) is. Ezen túlmenően a vérnyomás is csökken (a glucosuria mellett natriuresis és fokozott diuresis jelentkezik) (1. ábra).
A gyógyszercsoportban elsőként az EMPAREG OUTCOME tanulmány keretein belül az empagliflozin hatóanyagot tesztelték a kardiovaszkuláris biztonságosság szempontjából. Fontos megemlíteni, hogy a tanulmányba magas $\mathrm{CV}$ rizikójú cukorbetegeket vontak be, akiknél a standard gyógyszeres kezelés mellett alkalmazták a vizsgálati készítményeket. A vizsgálatban az empagliflozin szignifikáns mértékben csökkentette a CV események ( 3 pontos MACE) számát $(\mathrm{HR}=0,86$; 95\%-os CI: 0,74-0,99; $\mathrm{p}=0,04){ }^{22}$

$\mathrm{Az}$ összetett végponton belül a kardiovaszkuláris halálozás csökkenése volt a legjelentősebb tényező. Ugyanakkor a tanulmány legfigyelemreméltóbb eredménye a szívelégtelenség miatti hospitalizációk számában észlelt kifejezett csökkenés volt ( $\mathrm{HR}=0,65 ; 95 \%$-os CI: $0,5-0,85 ; \mathrm{p}=0,002)$. A csoportok közti különbség már nagyon korán megjelent, az utánkövetés végére pedig még tovább fokozódott. Fontos hangsúlyozni, hogy a tanulmányt nem az empagliflozin szívelégtelenségre kifejtett hatása céljából tervezték meg; a vizsgálatban mindössze $10 \%$ volt a korábban már szívelégtelenség miatt kezelt cukorbeteg. Ugyanakkor az alcsoport-analízisek igazolták, hogy a kedvező hatás mind a már szivelégtelenség miatt gondozott, mind a korábban még szívelégtelenség miatt nem észlelt betegeknél megfigyelhető volt.

A szívelégtelenség miatti hospitalizációk számának drámai csökkenése a fent említett vércukrot, vérnyomást és testsúlyt is csökkentő hatással csak részben magyarázható. ${ }^{23} \mathrm{Az}$ elért eredményekben a glukotoxicitás és az oxidatív stressz mérséklődése mellett a szívelégtelenségben központi szerepü RAS rendszer aktivitásának csökkenése is közrejátszhat. Emellett csökken az albuminuria, a hiperfiltráció és mérséklődik a nefronvesztés, ezek következtében pedig javul a vesefunkció. Ezen változások az artériás merevséget, a szív elő- és utóterhelését, vagyis a szív munkáját is jelentősen mérséklik (1. ábra).

A CANVAS vizsgálatban tesztelt canagliflozin lényegében az empagliflozinhoz hasonló, bár statisztikailag gyengébb eredményeket ért el; a CV események és a szívelégtelenség miatti hospitalizációk számának tekintetében a placebóval való összehasonlítás során szuperioritás igazolódott $(\mathrm{HR}=0,86 ; 95 \%$-os CI: 0,75-0,97; $\mathrm{p}=0,02$ és $\mathrm{HR}=0,67$; $95 \%$-os CI: $0,52-0,87$ ). A vizsgá- 


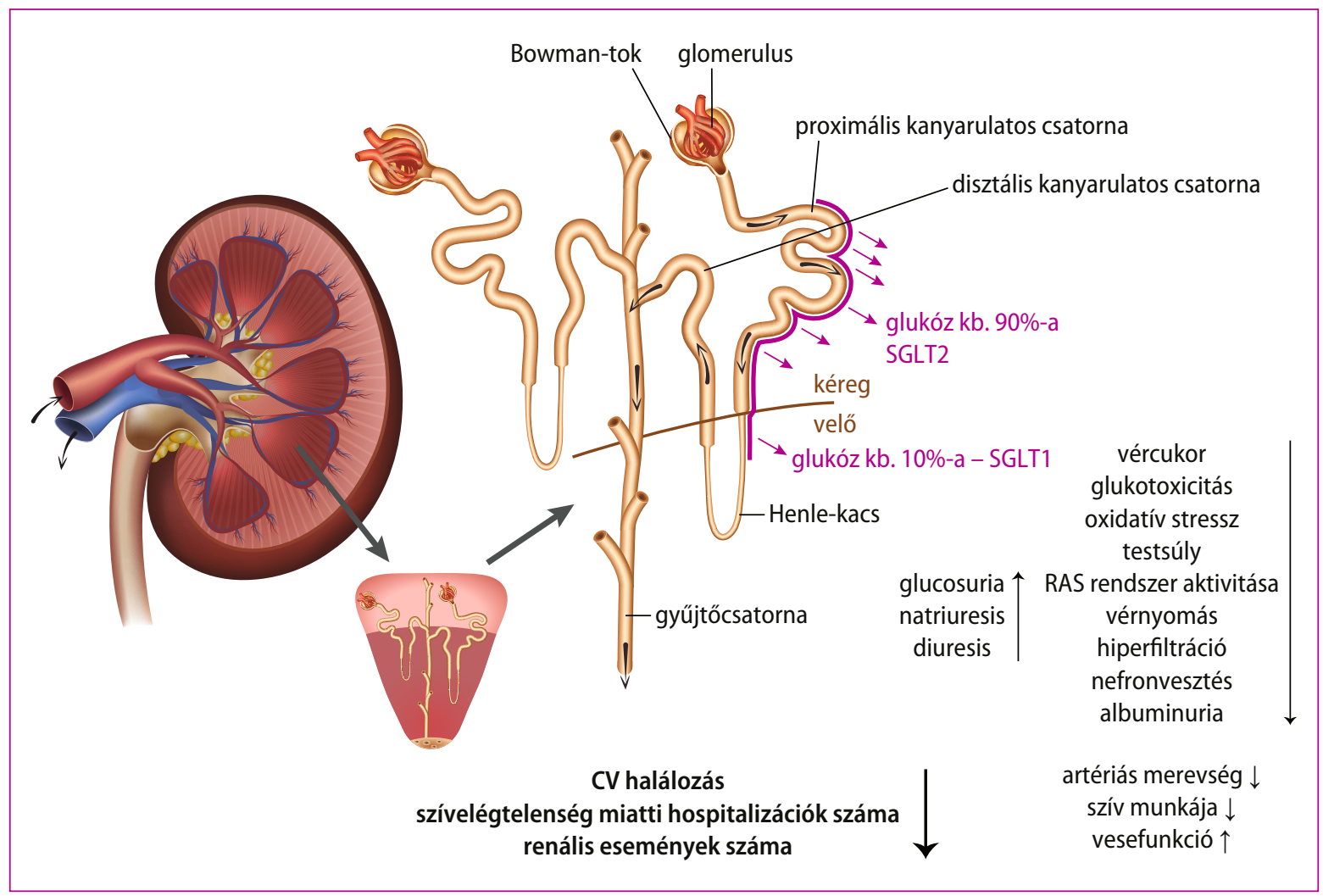

\section{1. ábra. Az SGLT2-gátlók hatása}

lat ugyanakkor egy meglepő, negatív eredménynyel is szolgált; eszerint a canagliflozin csoportban az alsó végtagi (főleg lábujj és lábközép) amputációk számának fokozódását észlelték $(6,3$, illetve 3,4 eset/1000 betegév; $H R=1,97 ; 95 \%$-os CI: 1,41-2,75). Emellett a csonttörések számának növekedése is detektálható volt, de ez összességében nem érte el a szignifikáns szintet. A negatív eredmények hátterében lévő mechanizmusok vizsgálata egyelöre még tart. ${ }^{24}$

Ugyanakkor fontos hangsúlyozni, hogy a jelen cikk megírásának pillanatában sem az empagliflozin, sem a canagliflozin nem rendelkezik jóváhagyott indikációval a kardiovaszkuláris események, halálozás vagy a szívelégtelenség miatti hospitalizáció rizikócsökkentésére.

Az idei évben került publikálásra egy nagy betegszámú, valóélet-adatokon alapuló vizsgálat, a CVD-REAL tanulmány. ${ }^{25}$ A vizsgálatban elsődleges végpontként az újonnan SGLT2-gátló terápiát kapó betegek szívelégtelenség miatti hospitalizációinak alakulását és az összhalálozást vetették öszsze más antidiabetikus terápiát kapó cukorbetegek adataival. Az elemzés első kohorszába 6 ország (Egyesült Államok, Nagy Britannia, Svédország, Dánia, Norvégia és Németország) nemzeti beteg- és halálozási regisztereiből retrospektív módon nyert adatokat használtak fel. Tekintettel arra, hogy az összhalálozási adatok Németországban nem voltak elérhetőek, ezért ezen végponthoz a másik 5 országból egy második kohorszt is kiválasztottak. A vizsgálatba olyan 18 évnél idősebb, 2-es típusú cukorbetegek adatai kerülhettek be, akikről a regiszterekben legalább egy évnél régebbi anamnesztikus adatok is rendelkezésre álltak, és az antidiabetikus terápia részeként SGLT2-gátló készítmény vagy más típusú vércukorcsökkentő terápia indult újonnan. Az egyes országok tekintetében a vizsgálat elindulását az első SGLT2-gátló készítmény országos bevezetésétől fogva datálták, 
míg lezárását az egyes regiszterek utolsó elérhető adatpontja szabta meg. A medián utánkövetési idő 0,9 év volt. Az első kohorsz tekintetében a fenti kritériumoknak összesen közel 1300000 beteg felelt meg. Az SGLT2-gátló készítményt használó populációhoz megfeleltetési párosítás révén választottak más típusú antidiabetikus terápián lévő betegeket. Ennek eredményeként a vizsgálatba 1:1 arányban összesen 309046 beteg került be. A csoportok epidemiológiai adatai (átlagéletkor: 57士10 év, női nem: 44,4\%, igazolt CV alapbetegség: $13,0 \%$, mikrovaszkuláris szövődmény: $27,3 \%$ ) és gyógyszeres terápiája (antihipertenzív kezelés: 80,0\%, statin: $67,3 \%$, metformin: $79,25 \%$, szulfanilurea: 38,55\%, DPP-4-gátló: 32,85\%, GLP1-agonista: 18,9\%, inzulin: $29,35 \%$ ) lényegében teljesen megegyezett. Az SGLT2-gátlót szedő csoportban a betegek 52,7\%-a canagliflozin-, 41,8\%-a dapagliflozin- és 5,5\%-a empagliflozin-terápiában részesült. Ezen túlmenően a Németországból származó összhalálozási adatok kiesésével a második kohorsz két csoportjába összesen 215622 beteg került beválasztásra. Az SGLT2-gátlók megoszlása ebben a kohorszban is hasonlóan alakult. Az adatok elemzésekor a szívelégtelenség miatti hospitalizációk számában 39\%-os ( $\mathrm{HR}=0,61 ; 95 \%$ os CI: 0,51-0,73; p=0,001), míg az összhalálozás terén $51 \%$-os $(\mathrm{HR}=0,49$; 95\%-os CI: $0,41-0,57$; $\mathrm{p}=0,001)$, szignifikáns, relatívkockázat-csökkenést találtak az SGLT2-gátló terápián lévő csoportban. Az eredmények az összes ország tekintetében hasonlóan alakultak.

Ezen túlmenően a tanulmány CVD-REAL Nordic alvizsgálatában ${ }^{26}$ a dapagliflozin és a DPP4-inhibitor terápia mellett előforduló szívelégtelenség miatti hospitalizációk számát és az összhalálozás rizikóját hasonlították össze a valós klinikai gyakorlat körülményeit reprezentáló dán, svéd és norvég nemzeti egészségügyi regiszterek adatainak elemzésével. Az elemzésbe a 2013 és 2016 között antidiabetikus terápián lévő cukorbetegek közül azok kerültek be, akiknél újonnan SGLT2gátló vagy DPP-4-inhibitor kezelés beállítása történt. A medián utánkövetési idő 0,95 év volt. A bevonás során a fent már említett megfeleltetési párosítást alkalmazva 1:3 arányban (dapagliflozin: $\mathrm{n}=10227$; DPP-4-gátló: $\mathrm{n}=30681$ ) választották ki a két populációt. A csoportok epidemiológiai adatai ezen alvizsgálatban is lényegében megegye- zett a két csoportot illetően. Az adatok elemzése a szívelégtelenség miatti hospitalizációk számában (HR=0,62; 95\%-os CI: 0,50-0,77; p=0,001), a MACE-ben $(\mathrm{HR}=0,79$; 95\%-os CI: 0,67-0,94; $\mathrm{p}=0,006)$ és az összhalálozásban $(\mathrm{HR}=0,59 ; 95 \%$ os CI: $0,49-0,72 ; p=0,001)$ is szignifikáns, relatívkockázat-csökkenést igazolt a dapagliflozin-terápiában részesülő csoportban.

A randomizált klinikai tanulmányokban szigorú beválasztási és kizárási kritériumokat alkalmazva erősen szelektált betegpopulációkat hoznak létre. A vizsgálat során prospektív utánkövetést alkalmazva egy előre meghatározott kezelési rezsim hatásait vizsgálják. Ezzel szemben, a valóélet-adatok elemzésekor a vizsgálatba mindennapos orvosi döntések nyomán meghozott terápián lévő, átlagos betegek adatai kerülnek feldolgozásra. Az eredmények súlyát a kifejezetten magas elemszám és a robusztus statisztikai módszerek alkalmazása biztosítja. Az ilyen jellegü vizsgálatok hátrányaként a retrospektív, regisztereken alapuló adatelemzést lehet megemlíteni. Mivel eltérő vizsgálómódszerekről van szó, ezért a valóélet-vizsgálatok jól kiegészítik, és akár előre is jelezhetik a randomizált klinika tanulmányok eredményeit.

A CVD REAL tanulmányban több mint 300000 cukorbeteg adatainak feldolgozásával közel 200000 betegév elemzését végezték el. Az SGLT2-gátló készítményt szedő csoportban jelentős csökkenést találtak az összmortalitás terén és a szívelégtelenség miatti hospitalizációk számában a többi antidiabetikus terápiát használó csoporttal szemben. A tanulmány jelentőségét kiemeli, hogy a bevont betegek $87 \%$-a CV betegséggel nem rendelkezett, így a vizsgálat primer prevenciós szempontból is jelentős eredményt ért el, és az SGLT2-gátló készítmények többi antidiabetikus terápiával szembeni hatékonyságát bizonyítja. A CVD REAL Nordic vizsgálat pedig az egyik SGLT2-gátló készítmény, a dapagliflozin szignifikáns előnyét igazolta a DPP-4-gátló készítményekkel szemben az összmortalitás, a MACE és a szívelégtelenség miatti hospitalizációk terén. Habár a dapagliflozin sem rendelkezik jóváhagyott indikációval a kardiovaszkuláris események, halálozás vagy a szívelégtelenség miatti hospitalizáció rizikócsökkentésére, de a fenti valóélet-adatokon alapuló vizsgálatok eredményei előre jelezhetik a CV 
események dapagliflozin-terápia melletti kisebb számban való előfordulását.

A több mint 17000 bevont beteggel jelenleg is folyamatban lévő DECLARE-TIMI 58 randomizált klinikai tanulmány a dapagliflozin kemény, $\mathrm{CV}$ végpontokra kifejtett hatását vizsgálja. A vizsgálat befejezése 2019-ben várható.

\section{Záró gondolatok}

Az antidiabetikumokkal elvégzett tanulmányok igazolták, hogy a vércukorszint sikeres csökkentésével a mikrovaszkuláris szövődmények kialakulása késleltethető, ugyanakkor a makrovaszkuláris komplikációk tekintetében hosszú ideig sikeres terápiás lehetőségről nem beszélhettünk. Az utolsó évtizedben az antidiabetikus készítmények tekintetében a $\mathrm{CV}$ biztonságosság kérdése vált a központi tényezővé. Éppen ezért a terápia megválasztása során kardiológiai szempontokat figyelembe véve biztonságos és lehetőség szerint $\mathrm{CV}$ rizikót csökkentő készítmény indítása előnyt élvez.

$\mathrm{Az}$ antidiabetikus terápia részeként metformin mellé a CV szempontból biztonságosnak tekintett DPP-4-gátló készítmények bátran kombinálhatóak; ugyanakkor szívelégtelen beteg esetén az alogliptin és a saxagliptin használata nem javasolható.

Kardiológiai szempontból az összes eddig vizsgált GLP-1-receptoron ható készítmény használata biztonságosnak tekinthető. További előnyöket nyújthat a liraglutid adása és piacra történő lépése után a semaglutid alkalmazása is.

A CV rizikó csökkentése és a szívelégtelenség miatti hospitalizációk megelőzése céljából a pozitív CV előnyökkel rendelkező SGLT2-gátlók használata kifejezetten javasolt, akár a metformin-terápia utáni első lépcsőben, akár későbbi kombináció részeként. A fenti randomizált klinikai tanulmányokon és az azokat kiegészítő valóélet-adatokon alapuló meggyőző eredmények (EMPA-REG OUTCOME, CANVAS, CVD-REAL, CVDREAL Nordic) hátterében feltehetően az SGLT2gátló készítmények gyógyszercsoport szintjén megjelenő hatása állhat. Az SGLT2-gátlók összetett hatásai mellett számos, mind ez idáig még ismeretlen mechanizmusok is hozzájárulhatnak a CV és a szívelégtelenség rizikóját csökkentő ered- ményekhez. Ezek mélyebb megismeréséhez a jövő vizsgálatai vezethetnek majd el.

\section{Köszönetnyilvánítás}

A cikk megjelenését az AstraZeneca Kft. támogatta. A közlemény a szerző saját véleményét tükrözi. $\mathrm{Az}$ AstraZeneca a gyógyszerei alkalmazását minden esetben az alkalmazási előírással összhangban javasolja.

A lezárás dátuma: 2018. 01. 04.

HU-0554 


\section{rrodalom}

1. Paneni F, Lüscher TF: Cardiovascular protection in the treatment of type 2 diabetes: a review of clinical trial results across drug classes. Am I Cardiol 2017; 120(1S): S17-S27. doi:10.1016/j.amjcard.2017.05.015.

2. Hayward RA, Reaven PD, Wiitala WL, Bahn GD, Reda DJ, Ge L, et al.: Follow-up of glycemic control and cardiovascular outcomes in type 2 diabetes. N Engl J Med 2015; 372(23):2197-2206. doi:10.1056/NEJMoa1414266.

3. Bugger $\mathrm{H}$, Abel ED: Molecular mechanisms of diabetic cardiomyopathy. Diabetologia 2014; 57(4): 660-671. doi:10.1007/s00125-014-3171-6.

4. Lloyd-Jones DM, Larson MG, Leip EP, Beiser A, D'Agostino RB, Kannel $W B$, et al: Lifetime risk for developing congestive heart failure: the Framingham Heart Study. Circulation 2002; 106(24): 3068-3072. doi:10.1161/01.CIR.0000039105.49749.6F.

5. Milligan S: Combination therapy for the improvement of long-term macrovascular and microvascular outcomes in type 2 diabetes: rationale and evidence for early initiation. J Diabetes Complications 2016; 30(6): 1177-1185. doi:10.1016/j.jdiacomp.2016.03.010.

6. Avogaro A, Fadini GP, Sesti G, Bonora E, Del Prato S: Continued efforts to translate diabetes cardiovascular outcome trials into clinical practice. Cardiovasc Diabetol 2016; 15(1): 111. doi:10.1186/s12933-016-0431-4.

7. Upadhyay J, Polyzos SA, Perakakis N, Thakkar B, Paschou SA, Katsiki $\mathrm{N}$, et al.: Pharmacotherapy of type 2 diabetes: an update. Metabolism doi:10.1016/j.metabol.2017.08.010.

8. Inzucchi SE, Bergenstal RM, Buse JB, Diamant M, Ferrannini E, Nauck M, et al: Management of hyperglykaemia in type 2 diabetes, 2015: a patientcentered approach. Update to a position statement of the American Diabetes Association and the European Association for the Study of Diabetes. Diabetes Care 2015; 38(1): 140-149. doi:10.2337/dc14-2441.

9. Gaál Zs, Gerö L, Hidvégi T, Jermendy Gy, Kempler $P$, Winkler G, et al:: Egészségügyi szakmai irányelv - A diabetes mellitus kórismézéséról a cukorbetegek antihyperglykaemiás kezelésérool és gondozásáról felnôttkorban. Diabetologia Hungarica 2017; 25(1): 3-77.

10. Holman RR, Coleman RL, Chan JCN, Chiasson JL, Feng H, Ge J, et al.: Effects of acarbose on cardiovascular and diabetes outcomes in patients with coronary heart disease and impaired glucose tolerance (ACE): a randomised, doubleblind, placebo-controlled trial. Lancet Diabetes Endocrinol 2017; 5(11): 877-886. doi:10.1016/52213-8587(17)30309-1.

11. Nissen SE, Wolski K: Effect of rosiglitazone on the risk of myocardial infarction and death from cardiovascular causes. N Engl J Med 2007; 356(24): 2457-2471. doi:10.1056/NEJMoa072761.

12. Scirica BM, Bhatt DL, Braunwald E, Steg PG, Davidson J, Hirshberg $B$, et al: Saxagliptin and cardiovascular outcomes in patients with type 2 diabetes mellitus. N Engl J Med 2013; 369(14): 1317-1326. doi:10.1056/NEJMoa1307684

13. White WB, Cannon CP, Heller SR, Nissen SE, Bergenstal RM, Bakris GL, et al: Alogliptin after acute coronary syndrome in patients with type 2 diabetes. $N$ Engl J Med 2013; 369(14): 1327-1335. doi:10.1056/NEJMoa 1305889.

14. Green IB, Bethel MA, Armstrong PW, Buse JB, Engel SS, Garg J, et al.: Effect of sitagliptin on cardiovascular outcomes in type 2 diabetes. N Engl J Med 2015; 373: 232-242. doi:10.1056/NEJMoa1501352.

15. Pfeffer MA, Claggett B, Diaz R, Dickstein K, Gerstein HC, Køber LV, et al: Lixisenatide in patients with type 2 diabetes and acute coronary syndrome. N EnglJ Med 2015; 373(23): 2247-2257. doi:10.1056/NEJMoa1509225.

16. Holman RR, Bethel MA, Mentz RJ, Thompson VP, Lokhnygina Y, Buse JB, et al: Effects of once-weekly exenatide on cardiovascular outcomes in type 2 diabetes. N Engl I Med 2017; 377(13): 1228-1239. doi:10.1056/NEJMoa1612917.
17. Marso SP, Bain SC, Consoli A, Eliaschewitz FG, Jódar E, Leiter LA, et al: Semaglutide and cardiovascular outcomes in patients with type 2 diabetes. N Engl J Med 2016; 375(19): 1834-1844. doi:10.1056/NEJMoa1607141.

18. Marso SP, Daniels GH, Brown-Frandsen K, Kristensen P, Mann JF, Nauck MA, et al.: Liraglutide and cardiovascular outcomes in type 2 diabetes. N Engl J Med 2016; 375(4): 311-322. doi:10.1056/NEJMoa1603827.

19. Raz I, Wilson PW, Strojek K, Kowalska I, Bozikov V, Gitt AK, et al: Effects of prandial vs. fasting glycemia on cardiovascular outcomes in type 2 diabetes: the HEART2D trial. Diabetes Care 2009; 32(3): 381-386. doi:10.2337/dc08-1671.

20. Gerstein HC, Bosch J, Dagenais GR, Díaz R, Jung H, Maggioni AP, et al.: Basal insulin and cardiovascular and other outcomes in dysglycemia. N Engl J Med 2012; 367(4):319-328. doi:10.1056/NEJMoa1203858.

21. Marso SP, McGuire DK, Zinman B, Poulter NR, Emerson SS, Pieber TR, et al.: Efficacy and safety of degludec vs. glargine in type 2 diabetes. N Engl J Med 2017; 377(8): 723-732. doi:10.1056/NEJMoa1615692.

22. Zinman B, Wanner C, Lachin JM, Fitchett D, Bluhmki E, Hantel S, et al: Empagliflozin, cardiovascular outcomes, and mortality in type 2 Diabetes. N Engl J Med 2015; 373(22): 2117-2128. doi:10.1056/NEJMoa1504720.

23. Butler J, Hamo CE, Filippatos G, Pocock SJ, Bernstein RA, Brueckmann M, et al.: The potential role and rationale for treatment of heart failure with sodiumglucose co-transporter 2 inhibitors. Eur J Heart Fail doi:10.1002/ejhf.933.

24. Neal B, Perkovic V, Mahaffey KW, de Zeeuw D, Fulcher G, Erondu N, et al:: Canagliflozin and cardiovascular and renal events in type 2 diabetes. N Engl J Med 2017; 377(7): 644-657. doi:10.1056/NEJMoa1611925.

25. Kosiborod M, Cavender MA, Fu AZ, Wilding JP, Khunti K, Holl RW, et al: Lower risk of heart failure and death in patients initiated on sodium-glucose cotransporter-2 inhibitors vs. other glucose-lowering drugs: the CVD-REAL study (comparative effectiveness of cardiovascular outcomes in new users of sodium-glucose cotransporter-2 inhibitors). Circulation 2017; 136(3): 249-259. doi:10.1161/CIRCULATIONAHA.117.029190.

26. Persson F, Nyström T, Jørgensen ME, Carstensen B, Gulseth HL, Thuresson M, et al.: Dapagliflozin is associated with lower risk of cardiovascular events and all-cause mortality in people with type 2 diabetes (CVD-REAL Nordic) when compared with dipeptidyl peptidase-4 inhibitor therapy: a multinational observational study. Diabetes Obes Metab doi:10.1111/dom.13077.

Közlessre érkezett: 2017. november 20.

Közlésre elfogadva: 2017. december 7 .

A levelezésért felelös szerzö:

\section{Dr. Habon Tamás}

Pécsi Tudományegyetem, Klinikai Központ, I. Belgyógyászati Klinika, Kardiológiai és Angiológiai Tanszék

7624 Pécs, Ifjúság út 13.

E-mail: habon.tamas@pte.hu 